\title{
Role of Equb in Financing Micro and Small Business Enterprises in Konso
}

\author{
Addisu Karafo \\ Lecturer at Dilla University College of Business and Economics, Ethiopia \\ *Corresponding Author: adiszgreat@yahoo.com, +251926030518
}

Copyright $\bigcirc 2017$ by authors, all rights reserved. Authors agree that this article remains permanently open access under the terms of the Creative Commons Attribution License 4.0 International License

\begin{abstract}
The aim of this study was to assess the role of Equb in Micro and Small Business Enterprises finance in Konso. For this purpose, data was collected through questionnaire from Equb members as well as interviewing with Equb organizers and non Equb MSE owners. The respondents were selected using both proportionate stratified and random sampling techniques. Besides, the collected data were analyzed using descriptive narrations through concurrent triangulation strategy. The result revealed that, People joined Equb to dig up large amount of money, save and even get loans at the lowest interest. Banks/Micro Finance Institutions fail to cater for the saving and credit needs of poor and small business holders, mainly due to their lending terms and conditions of creating financial gap which informal financial institutions try to fill. In Konso, Equb dominates other sources in the finance establishment of Micro and Small Enterprises, expansion and their working capital finance, followed by personal saving, families and relatives.
\end{abstract}

Keywords RoSCA (Equb), MSE, Informal, Formal

\section{Introduction}

MSE enterprise development has been touted as one of the feasible means by which people who are not participating in the economy can enter it [1]. Many people in the rural areas engage themselves in micro and small business enterprises activities to make a living, but getting start up and working capital finance is the major obstacle for them [2].

Formal financial institutions have always been reluctant to offer services to small enterprises because they are assumed to be riskier investment for different grounds [2]. Because of this, individuals have devised many informal financial institutions typically RoSCA as an alternative means to achieve saving and improve access to credit [3].

Rotating saving and credit association are informal saving and credit institution where individuals agree to meet for a defined period of time to jointly save and borrow money [4]. It is an indigenous financial institution in Africa known as Equb in Ethiopia, Susu in Ghana, Esusu in Nigeria, Chiperegani in Malawi, Mchezo in Tanzania, and Tontiniers in francophone countries [5].

This study was focused on the role that Equb played in finance of MSE in Konso. The remaining parts of the study were structured as follow. The second section emphasizes statement of the problem followed by objectives, review of literature, methodology, results and discussions and lastly conclusion of the study.

\subsection{Statement of Problem}

Micro and small enterprises have generated considerable attention among policymakers, academicians and international agencies. They are important contributors to the economy of every country through creation of employment opportunities, training entrepreneurs, generating income and providing a source of livelihood for the majority of low income households [2]. However; they are constrained by a number of factors particularly access to finance according to Devereux and Sharp, 2006 cited by Abera et al. [6].

Because of the inaccessibility of formal institutions, MSEs arrange themselves to start business with resources from IFSs as stated by Haftu [7], for the reason that IFIs have considerable experience and knowledge about dealing with small business borrowers. But, not all of IFSs are always appropriate for enduring business problems, such as smoothing cash flow, instead they are characterized by small size loans with usurious interest and short credit period, so are risky sources for entrepreneurs [8].

Unlike other IFIs, however; RoSCA acts as a source easily accessed by MSE. Hence, operations are simple and can be understood easily. It promotes the viability of MSEs through enhancing own savings, conversion of savings into investment, reduces transaction costs in credit markets, and facilitates the sharing of knowledge and skills that are crucial for operating business and expansion of small firms into viable enterprises [9]. 
In Ethiopia, although the number of financial institutions in local credit market has increased since 1990, the degree of practical assistance provided by such financial institution to MSEs has not been improved much [9]. The majority of small and business enterprises still have only limited access to Bank service because it is too difficult for them to meet the demand for collateral and high interest rates of Banks. As a result, almost half of small business enterprises in Ethiopia have to raise funds needed for day-to-day operation from Equb schemes according to Mogues, 2004 cited by Bekele and Worku et al. [9].

The role of Equb has been the subject of extensive researchers. For instance it is used to purchase durable goods, as a commitment device and to share social life [10], to buy consumer durables, for consumption, investment and to support families and friends [4]. Moreover, it is stated that Equb helps individuasl to save money, finances SMEs, create social harmony, and meet urgent financial needs [11]. Aredo [12] also added that in rural Ethiopia about half of the Equbs funds are used for consumption purpose, clothing and household goods (32\%), purchase of assets $(10 \%)$, and other purposes $(8 \%)$, but funds from big urban based Equbs are used solely for investment in business, purchase of expensive durables or in house construction.

The existing literature gives accentuate to urban areas of the country and does not emphasize exactly to how Equb can be used as a source of finance for MSE. Thus; in addition to ascertain [12] result, this study fills the gap of literature by emphasizing how Equb is used as a source of finance for MSE.

\subsection{Objectives of the Study}

The objectives of this study include:

- Assessing why people join Equb with the availability of Banks/MFI,

- Ascertaining the financial gap of formal finance that is being filled by Equb,

- Assessing alternative informal sources of finance that supports MSE operations,

- Assessing how the money saved through Equb is used to finance MSE

\section{Review of Literature}

\subsection{Importance of Micro and Small Enterprises}

Micro and small business enterprises are recognized as integral component of economic development and crucial element in the effort to lift countries out of poverty [13]. For a country to reach its full potential in terms of economic and social development, it cannot afford to ignore the importance of its indigenous micro and small enterprises scale and the contributions that they make to the country's economy.
Micro and small business enterprises encourage the development of indigenous entrepreneurship, enhance regional economic balance and promote effective resource utilization. They also contribute to increasing tax-incomes for the government and enable the government in the long run to invest the money which can contribute to fulfill social objectives [14].

Moreover, MSE encourages rural industrialization and development, decentralization of industries; more equitable income distribution; the use of indigenous resources; earning of foreign exchange resources; creation of backward and forward linkages with existing industries and entrepreneurial development [14].

Most importantly, they tend to be far more innovative in developing indigenous or appropriate technology, which may later grown into pioneering technological breakthroughs [15]. They can also act as the seedbed for the development of entrepreneurial skills and innovation. They not only play an important part in the provision of services in the community, but also can make an important contribution to regional development programs [16].

\subsection{Rotating Saving and Credit Association (RoSCA)}

Rotating saving and credit association is a group of individuals who agree to meet for a defined periods of time to save and borrow together [17]. It is among the oldest and most prevalent saving institution [18].

The basic description of the associations is that a group of individuals will be gathered on a regular basis for a cycle of meetings. At each meeting all members contribute a fixed amount of money to a common pot which will be allocated to one of them randomly or by decision of the governing body of the group or through a bidding process. The latter is then excluded from the reception of the collective savings in subsequent meetings but is still obliged to contribute to the pot for the rest of the cycle. This process repeats itself until each member received the pot, which marks the end of a cycle [19].

The members are mainly poor individuals who have little access to formal savings and credit markets [20]. The participation is based on trust and social forces, and the desire to continue to be a member. Membership is often drawn from homogenous groups e.g. from the same ethnic background, same work place or same neighborhood.

It is informal traditional microfinance because like microfinance institutions they serve the formally an accessed and low income group of societies [16]. It is popular alternative to the risks of saving at home where family and relative may demand access to savings [21]. Since no money has to be retained inside the group, no record has to be kept unless otherwise stated [11]. These characteristics make the system a model of transparency and simplicity that is well adapted to communities with low level of literacy and weak systems for protecting collective property rights. 


\subsection{RoSCA and Micro and Small Business Enterprises}

Micro and Small Enterprises (MSEs) are commonly believed to have very limited access to deposits, credit facilities and other financial support services provided by formal financial institutions. This is because, on one hand, these MSEs cannot provide the necessary collateral security demanded by these formal institutions and on the other hand, the banks find it difficult to recover the high cost involved in dealing with small firms. In addition to this, the associated risks involved in lending to MSEs make it unattractive to the banks to deal with micro and small enterprises [22]. It is because of this that many entrepreneurs turn to rotating saving and credit association when seeking fund for their starting up, expansion and working capital finance.

A number of studies in many parts of the world particularly in developing countries show that the fund from RoSCA is used for businesses starting up, expansion and other purposes. For instance, as a source of businesses start-up [23], as a source of credit for MSE and to invest in real estate, farms, and a supermarkets in Kenya as per Wachtel [24], as a potential source of start-up and working capital for its members, to finance taxis and mini-buses in South Africa [1]. Moreover, the fund is also used to build hotels and high-rise apartments, finance complex import-export businesses, fund bars, restaurants, cinemas and Lorries for road transport as per International Herald Tribune, 1987 cited by Bouman et al., [25].

As the business grows from micro to small, medium and large the need and use of capital also increases and would fall back on informal financial sectors if cheap formal finances is not available [26]. So the firms may shift their source of finance from RoSCA to Banks and Microfinance institutions for large credit. However, thus RoSCA members as they once start financing their business with the money from RoSCA may not shift to formal sources of finance, because of the expensive service, uncomfortable procedure, lack of freedom in money usage and even more having a good experience with RoSCA by the members [11].

A chief concern of enterprises is to ensure sufficient working capital, especially when payments for goods sold or services provided are delayed. So, in addition to expansion, the members also use the fund from RoSCA to finance working capital to restock supplies which enable them to expand their output and earn a stream of profits [27].

In Ethiopia, Equb schemes provide credit to MSEs and the opportunity to save money for growth and development. MSEs neglected by formal financial institutions secure credit from Equb associations on easy terms. This is supported by studies like [28 and 12], [11], [4], [10] and [6].

\section{Methodology}

The purpose of this study was to assess the roll of Equb in financing MSEs. This informal sector is large in number, widely spread, lake formal records and found outside formal regulations. On the base of this, concurrent mixed research approach $[29]^{1}$ qualitatively emphasized $(\mathrm{QUAL}+\text { quan })^{2}$ was adopted for the reason that the use of quantitative and qualitative approaches in combination may provide a better understanding of research problems and complex phenomena than either approach alone [30].

The study was conducted by taking samples only from rural Konso by considering limitations that the researcher will face like cost, time and the familiarities that it needs with the area as well as underlying people. Even more, against the result of Aredo et al. [12] ${ }^{3}$ which states that in rural Ethiopia about $89 \%$ of the Equbs funds are used for consumption purpose, clothing and household goods.

The participants for the study consists of traders, farmers, food seller, teachers and others in Konso who are members of Equb group and other non Equb SME owners. The study was carried out using twenty Equbs selected through the researcher's social network based on their site and importance to get the necessary information.

Hence the population from which a sample was to be drawn does not constitute a homogeneous group; both stratified purposive and simple random sampling techniques were used as sampling technique. These methods were used to accommodate the heterogeneous nature of the respondents and even to give equal chance of selection. However; taking the existing immense numbers of Equbs, this number seems not representative sample, but given the comparability in kind or nature and structure of their operations, a small number of units form a representative of the population [31].

The process of stratification was as follow:

- $1^{\text {st }}$ the Equbs under the study are classified in to two stratums as follows. ${ }^{4}$

Table 3. Equbs based on their periodic contribution, 2013

\begin{tabular}{|c|c|c|c|}
\hline Contribution & № of Equbs & No of members & Proportion \\
\hline Weekly & 12 & 1,005 & 0.737 \\
\hline Monthly & 8 & 358 & 0.263 \\
\hline Total & 20 & 1,363 & 1.000 \\
\hline
\end{tabular}

Source: personal survey, [2013]

- $2^{\text {nd }}$ proportionate stratified sampling is then used to draw a sample from each stratum in proportion to the latter's share in the total population.

1 Concurrent triangulation,

2 (Morse, 2003), mixed methods studies where the qualitative component has priority and the researchers identify themselves primarily as qualitative researchers.

3 To check the result, whether the majorities of Equbs in rural areas rely uses the lump sum for consumption, clothes and household goods as stated by Aredo (2004).

4 The surveyed Equbs are drawn based on their frequency of contribution as weekly or monthly 
Table 4. Proportionate stratification

\begin{tabular}{|c|c|c|}
\hline Contribution & $\begin{array}{c}\text { Computation of the } \\
\text { proportion }\end{array}$ & Sample \\
\hline Weekly & $0.737 \times 135$ & 100 \\
\hline Monthly & $0.263 \times 135$ & 35 \\
\hline Total & & 135 \\
\hline
\end{tabular}

Source: Personal survey, [2013]

- $\quad 3^{\text {rd }}$ simple random sample is then used to select the 135 participants from the strata (100 from weekly contributing Equbs and the rest from monthly contributing Equbs) just to give every element in the population the same chance of being selected.

Hence Equbs are informal institutions operating outside formal parameters; the study utilized only primary data collected through structured direct personal interview with Equb organizers as well as non Equb MSE owners. This technique was selected to have the same type of questions in the same order to each interviewee and also to get the benefits like safe basis for generalization.

Data was also collected through a self-administered questionnaire distributed to Equb members. The individuals who are literate filled questionnaire by themselves however; the data was besides collected using self-filled questionnaires from illiterate respondents. This technique is used to get the advantages like low cost, adequacy of time for respondents, free of interviewer's biases and reach a large number of respondents [32].

After collecting necessary data, they were examined for detection of errors and omissions through careful scrutiny of the completed questionnaires and put into a limited number of categories. The data collected through questionnaire was quantifiable, so was organized systematically and analyzed statistically with a statistical software SPSS (Statistical Package for the Social Sciences). Lastly, both interview data from organizers as well as non Equb MSEs owners and survey data of Equb members were merged together for a complete research report.

\section{Results and Discussions}

\subsection{Why do Peoples Join Equbs?}

A number of reasons pushed individuals to involve themselves in Equb. From the surveyed Equbs, the largest part participates in Equb to get large amount of capital that they would not have while saving personally. This is frequently for those who have the talent, ability and skill to create something for life and change for themselves, but limited financially. They try to solve it through saving personally but it takes long periods of time to have that large capital. Therefore; they approached Equbs or organized Equb by collaborating individuals that have similar ideas and problems.

In Konso, local consumption wipes out the money of the individuals that they generated from various sources. So to refrain from such wastage, individuals join Equb and put their money for something that gives value for them in the future i.e. as a commitment device just to save the money that they are abandon any time (31\%).

The surveyed Equbs open a group account and keeps in Bank/MFI or in their own custody, the entire first contribution, registration fee and penalties. This money is then used as a loan to the members and even to cover the reduction of lump sum amount because of the members default and other small expenses. Unlike formal institutions, however; as shown in various studies, Equb did not receive interest on the loan that they granted to its own members. Recent and modern Equbs introduced the way in which interests will be paid on the money borrowed, but the interest unlike Banks/MFI is very small. The lowest interest rate charged or interest free loans attract individuals to take part in Equb (17\%). Other join Equb to easy consumption, defend themselves against risks, purchase clothes, construction of houses, and share social life with others.

To support the above discussion, Equb organizers are interviewed and the interview provides other reasons why individuals joined Equb:

Joining a local Equb is the only way to save money because of the absence or recentness of formal sectors in Konso and people lacked awareness about them. In addition; if individuals leave the money at home without earning custody, it is subject to different risks and cannot earn interest. If they saved it in Bank/MFI it earns small amount of money that cannot match the amount to be earned in Equb. More over; People joined Equb to solve conflicts between wife and husband on the issue of either saving the money and the need for immediate consumption.

Non Equb MSEs owners are also interviewed why not they take party in Equbs like others and their stated that:

To participate in Equb depends on number of factors. For instance some individuals have enough wealth enabling them to live safety life, so they may participate in Equb, because they have the ability. For others who do not have such resource and who are labor workers to feed their lives, they may lake the ability.

When you save in Equb, there is probability of losing one's money because of the default or even the organizer himself may use and finally may not return the amount. This in turn needs us to bring the person to the community elders, Keble administrators and also to court which bring extra costs and wastage of time.

The time you are waiting until you obtain the lot have not difference to that of formal institutions if you are not the receiver of the first lot or particularly if you receive the lot after all, so you miss opportunities.

You may save in Equb by having certain objective that 
you want to achieve when wining the lot. But as you observe the current conditions in the market where the price of goods going up and up, how can you believe that saving in Equb assist one to achieve its future objectives. You will face a miss match between your objective and the conditions in the market because of the inflation.

\subsection{Formal Finance Provider's and Financial Gap}

In Konso Microfinance institution was established in 2006 and branch of Commercial Bank of Ethiopia recently in 2010. So for such long periods, people serve themselves using Equb and other informal sources of finance. Not only this, but after the establishments of the formal institutions, people wishes to stay in Equb hating the procedures and restrictions on the money usage and the follow up of the loan in the formal sectors. Moreover, MFI provides group loans where the behavior of the group may sometimes do not match one another increasing the probability of default which in turn makes the other members responsible, so they stay using Equb.

From the surveyed Equbs, 39\% of the participants' state that the physical collateral need and highest interest rate charged in formal institutions forces them to prefer Equb. In Equb, it needs commitment of the members their Equb to survive not physical collateral. But some Equb members fail to continue contribution after receiving the lot, to triumph over this, many Equbs developed a device a person winning a lot before the life cycle of Equb ends to present guarantors from the members to make sure that the winner continues contributions until the life cycle ends. If the winner failed to present guarantors, he/she is forced to receive fund at the end.

Equb continue to exist within in changing environments where formal financial institutions have been affected strongly. This makes individual members to continuously use it mounting good experience with it as stated by the surveyed Equbs (27\%). In addition, to borrow from Bank/MFI needs much information and also have cumbersome associated procedures which might not give comfort for the users of the service (waiting time, language problem, literacy obstacles, legal documents requests and others). So, instead of using formal services, peoples prefer Equb $(12 \%)$ hence, Equb is simple and does not have as such bulk procedures.

The organizer interviewed even added that the recentness of formal services, low interest on deposit and also high interest that they are charging on their loan causes them to use Equb. In addition, the winner of the lot instead of depositing the amount in the Bank buys livestock's either female cow to be kept for breeding or bull to feed either for farming or resale purposes.

The members are also asked whether they use loan at any time from the branch/MFI and around $84 \%$ responded that they have not applied loan because of the difficulty of their criteria, higher interest rate charge, lack of collaterals and even more, the information needs and procedures used by the Bank/MFI. Even more as per the organizer, the formal service is new in the woreda and the peoples lacked awareness about the uses and benefits. On the other hand, Equb has long periods of existences allowing the peoples to prefer it more than Bank/MFI.

\subsection{Other Informal Sources and Their Obtainability}

Entrepreneurs and MSE owners have many alternative informal sources of finance except for Equb. From the surveyed Equbs, the greater part of the members has relation with other informal sources of finance $(63 \%)$ and the rest (37\%) have no relation. As per response of the Equb organizer particularly for those whose weekly contribution exceeds Ethiopian Birr 1,000 acts as a money lenders by themselves if they do not need the money at the time they received the lot and do not need to sale or if there is no buyer among the members, they use their lot as a loan for other non Equb members. Other portrayed that at the time when the money from Equb is not available or if they do not need money from Equb, families and relatives use it to finance their activities.

They are also asked whether the money from such sources was available on time when needed and be enough to help them to achieve their intended objectives. $79.5 \%$ of the participants state that the money from sources other than Equb is not available on time and is not enough for the intended purposes.

As per the response of the members, such informal sources for instances families and relatives do not have such large money that will be provided for all like Banks/MFIs. They have no sufficient money because the money is not the money of group or deposit collected from other, but is the capital accumulated by single individual or family. Even more; they are few in number (mostly traders and wealthy peoples) and serve the need of certain groups that have the capacity of repaying the amount. While $20.5 \%$ states that the money is available on time and is enough for the intended purposes but is expensive mostly from money lenders.

\subsection{Equb and Other Informal Sources of Finance}

A person may need to finance its activities with money borrowed from formal financial institutions but getting Bank loan may not be easy, especially for people with little or no collateral, a bad credit rating and no prior business experience. Even if the loan is approved, interest payments will make it difficult to generate a profit. It is for these reasons that many entrepreneurs turn to friends, families and local money lenders when seeking funding for their needs. While this may seem like a great alternative to obtain credit, borrowing from such informal sources has certain challenges that the needy groups of people and small business owners.

The survey result shows that other informal financial 
institutions serves the users in one way either deposit or mostly credit (41\%). But unlike a one folded systems, Equb is a twofold system in that it accepts deposit weekly, biweekly or monthly from its members and also provides loan for its members.

In addition, Equbs unlike money lenders and traders have favorable interest rate for its members $(30 \%)$ or interest free loan and is easily accessible when needed $(12 \%)$. It is established by groups of people who are located in the same geographical location, belonging to the same religion or based on other grounds for certain cases (purposes), so once established, Equb is easily accessible for its members in terms time, cost and availability of the needed money.

The analysis of the data above is reinforced by interview of the Equb organizers. According to the interview:

Credit from moneylenders is good and best for MSE and the poor, but the short maturity periods and high interest rates do not make this credit attractive.

Friends and family loans may help in obtaining startup capital but they cannot be ongoing and thus are not easy to draw on for day to day business activities or the development of the enterprise. Financial disputes can even have devastating consequence and spoil personal relationships. If things don't go exactly as planned you may end up causing irreparable damage to the bonds you have with your loved ones.

Unlike other informal sources of finance Equb as a financial intermediary has both saving and borrowing sides allowing the users to save and also lend to others which make it attractive than other sources of finance.

One way to avoid the sudden costs charged by moneylenders is to borrow from neighbors and friends, but while interest rates maybe low (or even zero), social costs and obligations can be considerable. Equbs provide an alternative solution, based on pooling resources with a broad group of neighbors and friends.

\subsection{Purposes for Which Equb Fund is Used}

Equb have saving and credit aspects where by all members borrow from each other for varying periods of time and can be formed for various purposes such as; starting or expanding business ventures, consumption purposes or simply for saving as stated in the above discussions.

Peoples participate in Equb for different purposes mostly to save money that they are abandoning any at any time and to obtain credit. Entrepreneurs have a potential of creating activities that will change their life and the life of others, but they are restricted by shortage of money. They may save personally, but it takes many years to have large capital for investment, so they are forced to join Equb to have the bundle of group money. The surveyed Equbs allocated the lump sum money using lottery method, then after receiving the lot, they can use the money for different purposes.
From the survey, $40 \%$ of the participants said that they used the money as a source of startup capital for their business because they lack credit from formal sources. Most of the surveyed Equbs have long time existence before the establishment of Microfinance as well as Bank during the Derg regime with the initial contribution of 0.5 to 1.5 Birr for social self-help aspect but gradually come to Birr 100-3000 per week and monthly contribution. For this reason, the financially constrained rural peoples established Equb as advice to save and use the money to start business like cafes and restaurants, mobile centers, shops, wood work, hand crafts and others.

Equbs have been around for a long-periods and proof that they are very useful and solve financial problems for peoples. The users of the association develop experience well with it and in addition keep their source of finance for the coming activities of the business. The response of the participants' shows that, the experience that they have with Equb helps them to use the money for the expansion of their business even after the establishments of Bank and Micro finance $(20 \%)$.

The logic behind all firms is to generate sufficient profits and the extent to which profits can be earned depends among other things upon the size of the sales. A successful sales program is in other words, necessary for earning profits by any business enterprise. However, sales did not be converted into cash instantly; there is always a time-lag between the sale of goods and the receipt of cash. There is, therefore a need for working capital in the form of current assets to deal with the problem arising out of the lack of immediate realization of cash against goods sold. From the above figure $(15 \%)$ of the participants uses the amount that they receive from Equb to finance working capital. The reset states that the fund is used $(10 \%)$ to cover the costs of uncertain events like accidents of fire and healthy situations, to purchase durable goods $(9 \%)$ like cares, motorcycles, minibuses and even for consumption purposes $(6 \%)$, particularly funds from small Equbs.

\section{Conclusions}

As a financial intermediary, Equb acts as a saving and also a credit mechanism for all equally, but it was depend on the individual's ability in committing him or herself to make regular payments. People in Konso are far from formal financial services for many years. They start to use formal service from 2006 onward when Microfinance have been established for first time and commercial Bank branch in 2010. Within such long period of time, they use a traditional financial system as a means to save and obtain credit.

Peoples have a number of reasons why they join Equb even if formal financial services were available to them. From the discussion, the majority of the surveyed members joined Equb to dig up large amount of money that they cannot get while saving personally within short periods, to 
save the money that they are abandoning any time. Non Equb MSE owners, on the other hand, refuse to save their money in Equb because they have no transferred resources from their families, loose of opportunities, default among the members and even more inflation that badly disturb the current world.

Banks/MFIs fail to cater for the saving and credit needs of poor and small business holders, mainly due to their lending terms. From the discussion, people did not use credit from Bank/MFI, because of the highest interest rate, lack of collaterals and awareness about the usage and benefits of such sources. These created financial gap that is filled by informal institutions.

MSEs have a number of alternative informal sources of finance other than Equb like families, friends and money lenders. But, their amount of loan was insufficient, not available on time and is expensive. Even more, they are not ongoing and have devastating consequences and spoil personal relationships. Equb, on the other hand have both saving and borrowing aspects, favorable interest rate with little or no collateral making it preferable.

The absence of Bank/MFI or their recentness in the woreda rooted the use of Equb for different purposes. The scheme was predominantly accommodated for MSE's. They identified lack of access to financial services as one of the key constraints to the establishment, expansion as well as working capital finance. From the result of the study, Equb dominates other sources of finance in financing the establishment of MSE, expansion and their working capital finance, followed by personal saving, families and relatives.

\section{REFERENCES}

[1] Akwasi Arko-Achemfuor (2012), Financing Small, Medium and Micro-Enterprises (SMMEs) in Rural South Africa: An Exploratory Study of Stokvels in the Nailed Local Municipality, North West Province

[2] Fetene Zeru, (2010), "Access to Finance and its challenge for Small Business Enterprises: Case of Addis Ababa City", Research paper, Addis Ababa University.

[3] Mustafa Sawani, Seymour Patterson (2001), "Informal Saving Practices in Developing Countries," Journal of international business and cultural studies.

[4] Abbi M. Kedir \& Gamal Ibrahim, (2011), "ROSCA in urban Ethiopia: are the characteristics of the institution more important than the members", journal of development studies Vol. 47, No. 7, 998-1016.

[5] Hans Dieter Seibel \& U.G. Damachi, 1982: Self-Help Organizations: Guidelines and Case Studies for Development Planners and Field Workers. Bonn, Friedrich Ebert Foundation

[6] Admasu Abera, (2012), Factors Affecting the Performance of Micro and Small Enterprises in Arada and Lideta Sub-Cities, Addis Ababa.

[7] Haftu Berehanu, 2009, Financial needs of micro and small enterprise operators in Ethiopia, association of Ethiopian micro finance institution. Addis Ababa.

[8] Mohamadou L. Fadiga and Leslie A. Fadiga-Stewart, (2004), "Collective Action and Informal Financial Institutions: An Empirical Analysis of Rotating and Savings Credit Associations (ROSCAs) in Senegal," Paper prepared for presentation at the American of Agricultural Economics Association Annual Meeting.

[9] Eshetu Bekele and Zeleke Worku, (2008), "Factors that affect the long-term survival of Micro, Small and Medium enterprises in Ethiopia," South African Journal of Economics Vol. 76:3.

[10] Bisrat Agegnehu, (2012), "Why do members join indigenous informal financial institution: ROSCA?" an empirical evidence from equbs in Ethiopia, Environmental Economics and Management, Degree thesis No 710 ISSN 1401-4084.

[11] Temesgen, Teshome (2008), "Role and potential of Equb in Ethiopia," a project paper, Addis Ababa University.

[12] Dejene Aredo, (2004), “The Equb: Towards the quantification of the economic importance of an Ethiopian saving and credit association (RoSCA)," Ethiopia Journal of development research.

[13] Wolfenson, J. D. (2007). 'The Challenges of Globalization: the role of the World Bank. Paper presented at the address to the Bundestag Berlin, Germany.

[14] Mead D.C \& Liedholm (1998), "The Dynamics of Micro and Small Enterprises in Developing Countries". World Development, 26(1):61.

[15] Gebrehiwot Ageba and Wolday Amha, (2006), "Micro And Small Enterprises (Mses) Finance In Ethiopia: Empirical Evidence," Eastern Africa Social Science Research Review, Volume 22, Number 1, pp. 63-86 (Article)

[16] Joshua Alabi, Goski Alabi and Anthony Ahiawodzi, (2007), "Effects of susu - a traditional micro-finance mechanism on organized and unorganized micro and small enterprises (MSEs) in Ghana", African Journal of Business Management Vol. 1

[17] Adofu, Iet al. E., and Alabi,O. (2010), "Informal savings mobilization and investment: a case study of rotating savings and credit associations (RoSCA)" in kogi state, Nigeria, Continental J. Social Sciences 3: 7 - 17.

[18] Gugerty, M. K. (2007), "You can't save alone: commitment in rotating savings and credit associations in Kenya," Economic Development and cultural change, 55(2), 251-282. Doi: $10.1086 / 508716$.

[19] Christy Chung Hevener, 2006, Alternative financial vehicles: Rotating saving and credit association (ROSCA), Federal Reserve Bank of Philadelphia, discussion paper.

[20] Olivier Dagneliey and Philippe LeMay-Boucher, (2008), "RoSCA Participation in Benin: a Commitment Issue".

[21] Rutherford, Stuart (1999), "The Poor and Their Money - An Essay about Financial Services for Poor People", Institute of development policy and management, Manchester.

[22] World Bank (1994), Findings-Africa Region, Number 26, Washington DC.

[23] Kan, Kamhon, (2000), "Informal capital sources and household investment: Evidence from Taiwan," Journal of 
Development Economics

[24] Akoten, John E., Yasuyuki Sawada, and Keijiro Otsuka, (2006), "The determinants of credit access and its impacts on micro and small enterprises: The case of garment producers in kenya,"

[25] F.J.A. Bouman. 1995, Rotating and accumulating savings and credit associations: A development perspective, Agricultural University, Wageningen, The Netherlands.

[26] Ernest Aryeetey, (1998), "Informal finance for private sectors development in Africa," background paper prepared for the African development report

[27] Dejene, Aredo, (1993), "The informal and semi-formal financial sectors in Ethiopia: a case study of Equb, Iddir, and saving and Credit Co-operatives," African Economic
Research Consortium (AERC), Nairobi.

[28] Creswell, J. (2003), Research Design: Qualitative, Quantitativ e and Mixed Methods Approaches (2nd ed.), Sage, Thousand Oaks.

[29] Creswell, J.W., \& Plano Clark, V.L. (2011), "Designing and conducting mixed methods research" ( $2^{\text {nd }}$ ed.), Los Angeles, CA: Sag.

[30] Ritchie, Jane; Lewis, Jane \& Elam, Gillian (2003), "Designing and selecting samples," In Jane Ritchie \& Jane Lewis (Eds.), Qualitative research practice," A guide for social science students and researchers (pp.77-108) Thousand Oaks, CA: Sage.

[31] C.R.Kothari, (2004), "Research methodology: methods and techniques," second edition, new age international publishers. 